\title{
Professional Development Appraisal and Teacher Performance among Secondary Schools in Migori County
}

\author{
${ }^{1}$ Teresa Atieno Otieno*, ${ }^{2}$ Matula Phylisters and ${ }^{3}$ Okoth Ursulla \\ ${ }^{1,2,3}$ Department of Educational Administration and Planning University of Nairobi, P. O. Box Nairobi, \\ Kenya
}

\begin{abstract}
Performance appraisal forms an important practice in human resource management. In Kenya, the Teacher Performance Appraisal and Development (TPAD) has been used since 2012 as an appraisal approach to evaluate teachers' performance. However, the effectiveness of performance appraisal in enhancing teacher productivity as reflected in students; academic achievement has not been documented in Kenya and remains questionable. In Migori County, student performance in KCSE examination has been comparatively low. The objective of this study was to analyse the influence of professional development appraisal on teacher performance among public secondary schools in Migori County. Specific objectives were to determine the level of teachers' performance after evaluation, and to establish how appraisal of professional development influence performance of teachers. Descriptive survey design on a target population of 276 principals and 2961 teachers was employed in the study. Krejcie and Morgan (1970) table was adopted to derive a sample size of 342 teachers and 57 principals stratified based on school category population. Questionnaire and interview guide were used to collect data from teachers and principals respectively. The study found that there was a significant difference in the mean of teacher's performance after appraisal and the category of teachers' schools. The study also found that $64.1 \%$ changes in teachers' performance is attributed to professional development appraisal $\left(\mathrm{R}^{2}=0.641\right)$, and that professional development appraisal $(\beta=0.803)$ is a significant predictor of teacher performance $\left\{\mathrm{F}_{(1,278)}=493.200, \mathrm{P}<0.05\right\}$. The study concludes that professional development appraisal significantly contributes to performance of teachers in secondary schools.
\end{abstract}

Key Words: Professional Development; professional Development Appraisal; In-service Training; Performance of Teacher; Teacher Performance Appraisal and Development

\subsection{Introduction}

Teachers' continuing professional development (CPD) has become a major focus within the school reform and school improvement literatures because of the belief that student learning and success are due, in large part, to the effectiveness of teachers (OECD, 2009). Generally, teacher professional development refers to ongoing learning opportunities available to teachers and other education personnel to enhance individual's skills, knowledge, expertise and other characteristics as a teacher (OECD, 2009; Opfer \& David, 2011; Darling-Hammond, Hyler \& Gardner, 2017). Professional development is seen as an essential mechanism for enhancing teachers' content knowledge and improving their classroom practices. For improvement to student learning to be realised, then one pathway for doing so is the provision of more effective professional learning activities for teachers in schools; where these activities result in positive change for teachers and their pupils (Opfer \& David, 2011; Namamba \& Rao, 2017). Whereas various professional development approaches and their consequential benefits have been documented, studies regarding effectiveness of performance appraisal on the same in terms of teacher performance are scanty.

Performance Appraisal (PA) is one of human resource management practices that has been widely studied all over the world and has equally been identified as a strong motivator (Ademola 2017). According to Boyan (2013), performance appraisal is a tool utilized by organizations to evaluate employee's performance in relation to certain preestablished criteria and organizational objectives. This is a continuous process of identifying, measuring and assessing performance of every employee with a view of knowing the areas that need to be improved (Boko, Danku, Dordor \& Solgo, 2015). The information provided from performance appraisal is often used for, among other things, identifying training needs and recommending development approaches (Dessler, 2014; Kirai \& Kisang, 2016). It therefore emerges that, based on recommendations for development improvement, one of the key areas where performance appraisal is focused upon is employee professional development (Dessler, 2014). Performance appraisal on teacher 
professional development evaluates level of skills and competency possessed by teachers capable for meeting learning needs of students (Gichuki, 2015; Kareithi, 2018). However, the extent to which evaluation of professional development has enhanced performance of teachers is shrouded with lack of clarity. Moreover, whereas there are several approaches for professional development for teachers, their effectiveness resulting from appraisal reports lacks adequate documentation.

Migori County is one of the four counties dominated by communities sharing same social and cultural values: the Luo Community. The County has 276 public secondary schools. Between 2017 and 2020, the County has attained an average mean score of 5.360, as opposed to the leading Counties Homa Bay, which had 7.22 and 7.41 respectively (Table 1).

Table 1: KCSE Examination Mean Scores for Four Counties

\begin{tabular}{|l|c|c|}
\hline Sub County & Mean Score & Deviation from National Mean Score \\
\hline Homa Bay & 7.22 & 2.351 \\
\hline Kisumu & 6.57 & 2.712 \\
\hline Siaya & 7.41 & 1.365 \\
\hline Migori & 5.36 & 3.747 \\
\hline National Mean & $\mathbf{9 . 2 7 7}$ & $\mathbf{2 . 5 4 4}$ \\
\hline
\end{tabular}

Source: Migori County Education Office (2021)

Table 1 illustrates average mean score of academic performance of the 4 Counties in $2017-2020$ KCSE examinations. The table reveals that the mean score of Migori County $(5.36 ; \mathrm{SD}=2.347)$ was lower than the county mean of 5.247 during 2017. The large standard deviation (2.347) illustrates that the mean could be less or more by a value of 3.747. Similarly, the academic performance of students in Migori County was the lowest compared with other counties with similar socio cultural backgrounds. The Kenyan Government, through Teachers Service Commission (TSC) has rolled out a systematic appraisal tool, the Teacher Performance Appraisal and Development Tool (TPAD) for the purposes of promoting teacher performance and promotion of professional development. However, the extent to which this appraisal tool has enhanced performance of teachers and consequently student performance remains unknown. This warranted highlighting especially in Counties with teacher disatisfaction and low student achievement such as Migori County.

\section{Statement of the Problem}

Performance appraisal has been touted as an efficient tool in ensuring that, among other things, training and development needs of an employee are identified and remedied. Evaluation of professional development of teachers under TPAD tool has been an on-going exercise since 2012. However, its effectiveness in eliciting improved teacher performance as reflected in performance of students remain unclear. Furthermore, the exercise has received resistance from most teachers and the teacher Unions for its time - consuming nature. In addition, professional development appraisal of secondary school teachers and how it influence teacher performance remains questionable in areas such as Migori County where student performance is comparatively low.

\section{Main objective}

To explore the influence of professional development appraisal and teacher performance among secondary schools in Migori County

\section{Specific objectives}

The study was set to:

1. Determine the teachers' performance and the category of their schools after appraisal among public secondary schools in Migori County

2. Establish how the existing professional development appraisal influence teacher performance among public secondary schools in Migori County

\subsection{Literature Review}

In Turkey, Balta, Arslan \& Duru (2015) reviewed the literature that deal with the effects of in-service training (IST) on teacher achievements by means of meta-analysis. The effect sizes, obtained from these presented theses, were combined, a common effect size belonging to the efficiency of IST courses (Hedge's $g=3.819$ ) was calculated and the organized IST courses were determined to be highly effective within the thesis. It was revealed that there were not 
enough studies conducted in Turkey that measure the empirical effectiveness of IST and exploring the effectiveness of IST courses was demonstrated to be a virgin area for researchers.

Uysal (2012) evaluated a one-week INSET offered by the Turkish Ministry of Education to explore its sustained impact on language teachers' attitudes, knowledge-base, and classroom practices. The program is first evaluated against the criteria for effective INSETs suggested by previous literature. Then, data are gathered through course materials analysis, interviews with trainers and teachers, and through a questionnaire distributed to 72 teachers 18 months after the course ended. Findings indicate that although the teachers' attitudes are positive towards the course in general, the program has limitations especially in terms of its planning and devaluation phases, and its impact on teachers' practices.

In Madagascar, Raholdina-Razafimbelo, Razafimbelo, Ramanitra, Andrianavalonirina and Ratompomalala (2013) analyzed the teachers' network program to shed light on the contributions towards its collaborative learning device. Questionnaires, supplemented by interviews, were submitted to regional education officials and key actors involved directly in schools. Although "collaboration" is not really apparent in JP as there is neither voluntary work per se, nor symmetry criteria, "collaborative learning" can be observed in Teachers' Networks and is appreciated by INSET teachers. In fact, the findings reveal significant complementarities between JP and "Teachers' Networks".

Norwani, Daud, Mansor and Yusof (2017) explored the relationship between the level of in-service training (IST) needs and teachers' teaching skills to students' achievement in secondary schools in the state of Perak, Malaysia. Data was collected through questionnaire. The increase of teaching skills level is at a moderate level with a mean of 3.61. Results of the hypotheses testing showed that there was no significant relationship between demographic factors (gender, age and teaching experience) in the level of the IST needs and the teaching skills. The study found a weak significant relationship between IST needs with teaching skills and no significant relationship between teaching skills and students' achievement. Implications of the study include suggestions to improve the performance of IST and teaching skills in order to upgrade students' achievement.

Junejo, Sarwar and Ahmed (2017) examined the impact of in-service training on the performance of the teachers. It is generally believed that with the implementation of certain in-service training programmes the performance of teachers regarding their professional skills, knowledge and experience can be significantly improved. The target population of the present study included the in-service teachers offering their services at Sindh Technical Education \& Vocational Training Authority (STEVTA), Government of Sindh, Karaschi Region. Using close-ended questions, perception and experience of teachers $(n=150, m=100, f=50)$, who availed the opportunity to get in-service training, were gained. Findings of the study revealed the positive impact of in-service training programmes on the performance of teachers. The study also revealed the positive perception of teachers regarding their professional growth.

Kwaku and Mensah (2016) sought to investigate teachers' continuous professional development (CPD) and its influence on their classroom practices at the Kassena-Nankana West District in Ghana. From a population of 310, 93 basic school teachers were sampled using the simple random sampling technique. Findings revealed that teacher effectiveness was significantly related to effective teaching in basic schools. Similarly, basic school teachers reported that professional development programmes were relevant to their classroom management practices. Consequently, this study concluded that capacity building programmes should be promoted regularly to build basic school teachers capacity for effective teaching.

Adagiri (2014) provided a comparative theoretical analysis and empirical description of teachers' Continuing Professional Development (CPD) in Abuja and Portsmouth. The study uses qualitative research design and a combination of mixed methods including interviews, questionnaires and a comprehensive review of literature and documents over the last two decades. Findings suggest that teaching conditions and opportunities for CPD in both countries may differ based on contextual factors; however, there is a common drive towards professionalism and teacher quality. Better opportunity for teacher professional development exists in private schools in Abuja, which is attributable to more autonomy, competitive market and high demand for quality education.

Namamba and Rao (2017) examined teacher educators' preparation and professional development in the context of educational reforms and mushrooming of teacher education institutions in Tanzania. The document review method was used to analyze and review relevant literature. The analysis of findings indicates that the preparation of teacher educators in Tanzania receives considerable attention and focus in undergraduate programmes with little attention in postgraduate programmes. The professional development of teacher educators is limited and characterized by few professional development activities. It is suggested that the preparation of teacher educators should be well structured and enhanced with effective professional development activities and opportunities. 
Abong'o (2013) evaluated the effect of a programme: Strengthening Mathematics and Science Secondary Education (SMASSE) on teachers' pedagogical skills and attitudes to ascertain its relevance as an INSET programme. A descriptive survey research design was used in this study. The accessible population comprised all the SMASSE trained Biology teachers and the Biology students in Rachuonyo South district. Results indicated that the pedagogical skills scored higher on mean frequencies and effectiveness after SMASSE INSET than before. The findings showed that teachers' pedagogical skills and attitudes after SMASSE INSET were better than before the INSET.

Kareithi (2018) sought to determine the effect of performance appraisal on performance of secondary schools' teachers in Kirinyaga west Sub County. The study adopted a descriptive research design. The study's target population was 371 teachers in Kirinyaga West Sub-county. The study employed stratified random sampling technique in sample selection. The study sample size was 192 respondents. The study established that secondary school teachers agreed that goal setting practices has help them improve teaching methodologies (mean 3.198); The feedback received agrees with what teachers have actually achieved (mean 3.249); TSC pegs promotion on performance (mean 3.249). Further, the study results revealed a significant positive relation between goal setting practices, performance feedback practice as well as reward system practices and teachers' performance.

The reviewed studies have highlighted various approaches for providing professional development to teachers. It is however clear that the effectiveness of the professional development approaches reviewed are mixed: some elicit improvement in performance in some regions while some do not. Significantly, it should be noted that in all the approaches, the teacher professional development appraisal has not been linked to performance as reflected in student academic achievement. This study was set to fill this gap.

\section{Materials and methods \\ Research Design}

This study used descriptive survey research design with mixed method approach. Descriptive survey research design is appropriate in the collection of both quantitative and qualitative data. This research sought to collect both qualitative and quantitative first-hand information on influence of performance appraisal on the secondary school teachers' performance in Migori County. Creswell and Plano (2018) points out that descriptive surveys research seeks to obtain information that describes existing phenomena by asking individuals about their perceptions, attitudes, behaviours, experience or values. Similarly, Shorten and Smith (2017) contend that descriptive research studies are those concerned with describing the characteristics of a particular individual or group.

\section{Target Population and Sample Size}

The target population in this study comprised of 276 public secondary schools in Migori County. The study targeted 276 principals and 2961 teachers (CEO, 2019). From the target population, a sample size of 342 arrived at through Krejcie and Morgan table of 1970. The number of schools that participated in the study were 57 which represented 21 $\%$ of the 276 schools targeted. With a sample size of 342 teachers and 57 schools, it implied that around 6 teacher per school were to participate study

Stratified technique was applied to select teachers based on their school categories. These were National, Extracounty, County and sub-county schools. Stratified technique ensures that selection is based on the population strength in each category. According to Nanjundeswaraswamy and Divakar (2021), this method is most suitable when the population consist of heterogeneous sub-population groups. At every stratum the teachers were selected using simple random sampling. The 10\% (6) of principals and 6 HODS who participated in the study were purposively selected from the participating schools. Table 2 presents the distribution of sample size.

Table 2: Sampling frame for schools and Teachers

\begin{tabular}{|l|l|c|c|}
\hline $\begin{array}{l}\text { School } \\
\text { Category }\end{array}$ & No of schools & School Sample size & Samples size for teachers \\
\hline National & & & \\
Extra county & 2 & 2 & 12 \\
County & 23 & 5 & 30 \\
Sub county & 14 & 3 & 18 \\
& 237 & 47 & 282 \\
\hline Total & 276 & 57 & 342 \\
\hline
\end{tabular}

\section{Research Instruments}


The used questionnaire and interview guide for data collection. According to Matula et al. (2018) questionnaires are commonly used in surveys that involve human subjects and the researcher can gather data from a widely scattered sample. The questionnaire instrument was used on both Heads of Departments and teachers. Similarly, the data from the principals were gathered using interview guide as the study sought to get more in depth information with respect to how performance appraisal have influenced the teacher performance in Migori County. Interviews allow more indepth information to be obtained and has greater flexibility as the opportunity to restructure questions is always there. The information obtained from the interviews was recorded to ensure all the facts said in the session were captured.

\section{Validity of Instruments}

Instrument validity was measured by conducting content validity measurement. Content validity index (CVI) was used to measure the degree of which the instruments had appropriate items for measuring livelihood of households (Dawadi, Shrestha \& Giri, 2021). Four experts were asked to rate each scale item in terms of its relevance to the underlying constructs using a 4-point ordinal scale: $1=$ not relevant; $2=$ somewhat relevant; $3=$ quite relevant; $4=$ highly relevant. Then, for each item, the CVI was computed as the number of experts giving a rating of either 3 or 4 (thus dichotomizing the ordinal scale into relevant and not relevant), divided by the total number of experts. The instrument was rated as highly relevant by three out of four judges, giving a CVI of .80 .

\section{Reliability of Instruments}

Split-half method was done during pilot study with randomly selected 27 respondents to test instrument reliability. Internal consistency of the instrument was determined via split-half reliability index using Cronbach's Alpha coefficient (Cronbach, 1970, cited in Akhtar, 2016). This involved spliting the instrument questions into two halves of equal items then calculating the coefficients of each half (Taherdoost, 2016). The internal consistency (reliability) of the study generated an Alpha coefficient of 0.849 which is greater than the threshold 0.7 espoused by Creswell and Plano (2018)

\section{Data Analysis and Presentation}

Data collected was processed and analyzed using descriptive statistics: mean (M), and Standard Deviation (SD) with the aid of Statistical Package for the Social Sciences (SPSS) tool. Qualitative data obtained from interviews was analysed through Thematic Analysis. This entailed categorization of generated answers into outstanding themes and reported in narrative forms (Braun \& Clarke, 2019).

\section{Results and Discussions \\ Results}

Analysis of teachers' performance and the category of their schools

The study sought to establish how the category of schools related to their performance after appraisal. In order to analyze this, the following hypothesis was tested;

\section{There is no significant difference in the mean of teachers' performance after appraisal and the category of the schools}

Table 3 shows teachers performance after appraisal in terms of means and standard deviation in relation to the category of schools.

Table 3: Teachers performance after appraisal and their years in teaching

\begin{tabular}{|l|c|c|c|}
\hline \multirow{2}{*}{ School Category } & \multicolumn{3}{|c|}{ Teachers' performance } \\
\cline { 2 - 4 } & $\mathrm{N}$ & Mean & Std. Deviation \\
\hline National & 10 & 27.60 & 8.058 \\
\hline Extra County & 27 & 39.56 & 7.929 \\
\hline County & 13 & 42.92 & 4.425 \\
\hline Sub county & 228 & 34.90 & 11.536 \\
\hline Total & $\mathbf{2 7 8}$ & $\mathbf{3 5 . 4 7}$ & $\mathbf{1 1 . 1 6 5}$ \\
\hline
\end{tabular}

Table 3 shows means for teachers in County schools was 42.92 followed by the mean for those teachers in Extra County and Sub County at 39.56 and 34.90 respectively. These three means implies that teacher in those categories of schools agree that their performance had improved after appraisal. This can be interpreted to imply that teachers in the three category of schools learn a lot from teacher appraisal exercise that has mad them to register improvement in their performance. It is only teachers in the National schools who were neutral $(M=27.60)$ on whether their performance had improved after appraisal. 
Given the above result, the study sought to investigate whether the difference in means posted in various categories of schools was significant. This led to the testing of the third null hypothesis using ANOVA test. The results were as shown in table 4

Table 4: ANOVA analysis of teachers' category of schools and their performance after appraisal

\begin{tabular}{|l|c|c|c|c|c|}
\hline & Sum of Squares & Df & $\begin{array}{c}\text { Mean } \\
\text { Square }\end{array}$ & F & Sig. \\
\hline Between Groups & 1865.342 & 3 & 621.781 & 5.216 & .002 \\
\hline Within Groups & 32661.867 & 274 & 119.204 & & \\
\hline Total & $\mathbf{3 4 5 2 7 . 2 0 9}$ & $\mathbf{2 7 7}$ & & & \\
\hline
\end{tabular}

Table 4.13 shows $\mathrm{F}=5.216$ and $\mathrm{df}=3$ and a $\mathrm{P}$ - value of 0.002 . Since the P-value is less than 0.05 level of significant, the null hypothesis that 'There is no significant difference in the mean of teachers' performance after appraisal and the category of the teachers' schools, was therefore rejected. It was therefore concluded that there is a statistical significant difference in the mean of teachers' performance after appraisal and their category of schools. This implies that teachers in other category of schools learned a lot from the teacher appraisal exercise

\section{Professional development Performance Appraisal and Teacher Performance}

This section focuses on how performance appraisal on professional development influence teachers' performance. Means and standard deviation for performance appraisal on professional development

The respondents were asked to rate the items on a scale of 1 - Strongly Disagree, 2 - Disagree, 3 Neutral, 4 - Agree and 5 - Strongly Agree. The results were analyzed and presented in terms of means standard deviation as shown in table 5 .

\section{Table 5: Performance appraisal on professional development}

\begin{tabular}{|c|c|c|c|c|c|}
\hline & ITEMS & $\mathbf{N}$ & $\begin{array}{c}\text { Mea } \\
\text { n }\end{array}$ & $\begin{array}{l}\text { Std. } \\
\text { Error }\end{array}$ & $\begin{array}{c}\text { Std. } \\
\text { Deviation }\end{array}$ \\
\hline & $\begin{array}{l}\text { Appraisal on professional development has } \\
\text { enhanced my participation in marking of exams } \\
\text { at different levels }\end{array}$ & $\begin{array}{c}27 \\
8\end{array}$ & 3.18 & .080 & 1.341 \\
\hline 2. & $\begin{array}{l}\text { Appraisal on professional development has } \\
\text { enhanced my involvement in subject panels at } \\
\text { different levels }\end{array}$ & $\begin{array}{c}27 \\
8\end{array}$ & 3.40 & .082 & 1.363 \\
\hline & $\begin{array}{l}\text { The Appraisal on professional development has } \\
\text { enhanced my participation in training programs. }\end{array}$ & $\begin{array}{c}27 \\
8\end{array}$ & 3.54 & .074 & 1.242 \\
\hline 4. & $\begin{array}{l}\text { Appraisal on professional development has } \\
\text { improved my attainment of certificates for } \\
\text { courses attended }\end{array}$ & $\begin{array}{c}27 \\
8\end{array}$ & 3.47 & .083 & 1.387 \\
\hline & $\begin{array}{l}\text { Appraisal on professional development has } \\
\text { improved my enrolment as a teacher in } \\
\text { professional development courses }\end{array}$ & $\begin{array}{c}27 \\
8\end{array}$ & 3.45 & .075 & 1.250 \\
\hline 6. & $\begin{array}{l}\text { Appraisal on professional development has } \\
\text { enhanced my professionalism. }\end{array}$ & $\begin{array}{c}27 \\
8\end{array}$ & 3.54 & .075 & 1.256 \\
\hline & $\begin{array}{l}\text { Appraisal on professional development has } \\
\text { enhanced my professional advancement. }\end{array}$ & $\begin{array}{c}27 \\
8\end{array}$ & 3.55 & .075 & 1.258 \\
\hline 8. & $\begin{array}{l}\text { Appraisal on professional development has } \\
\text { enhanced understand my future needs for } \\
\text { professional advancement }\end{array}$ & $\begin{array}{c}27 \\
8\end{array}$ & 3.59 & .071 & 1.188 \\
\hline & $\begin{array}{l}\text { Appraisal on professional development has } \\
\text { enhanced select training suitable for my } \\
\text { professional development }\end{array}$ & $\begin{array}{c}27 \\
8\end{array}$ & 3.56 & .074 & 1.238 \\
\hline & $\begin{array}{l}\text { Appraisal on professional development has } \\
\text { enhanced understand has made me very relevant }\end{array}$ & $\begin{array}{c}27 \\
8\end{array}$ & 3.53 & .072 & 1.195 \\
\hline
\end{tabular}

Table 5 shows that the lowest mean registered was 3.18 and the highest mean was 3.59. Since the lowest mean in slightly above 3.00 , it is interpreted to mean neutral while the highest mean of 3.59 is above 3.50 and thus is said to 
tend towards 4.00 which means 'agree'. This therefore shows that respondents' opinion on Performance appraisal on professional development variable tended to vary from neutral to agree. The standard error of the mean on all 10 items ranges between 0.071 to 0.083 appear to be smaller enough to enable us conclude that the sample means on the 10 items are true representative of the population from which the sample was drawn from. Among the items that teachers agreed that appraisal has enabled them to improve include; understand their future needs for professional advancement $(\mathrm{M}=3.59)$, select training suitable for my professional development $(\mathrm{M}=3.56)$, enhanced my professional advancement $(\mathrm{M}=3.55)$

The study further sought to establish the composite mean for all the 10 items on Performance appraisal on professional development. The likert type data was transformed to continuous variable to enable computations of composite mean. The general mean (Composite mean) was interpreted base on the score for 10 items for each respondent. This score ranges between 10 (if the responded rated strongly disagree on the 10 items i.e $1 \times 10$ ) and 50 (if the respondent rated strongly agree on the 10 items $5 \times 10$ ). The result of analysis were reported in table 6 .

Table 6: Composite mean on items under Performance appraisal on professional development

\begin{tabular}{|c|c|c|c|c|c|}
\hline $\mathbf{N}$ & $\begin{array}{c}\text { Minimu } \\
\text { m }\end{array}$ & $\begin{array}{c}\text { Maximu } \\
\text { m }\end{array}$ & Mean & $\begin{array}{l}\text { Std. } \\
\text { Error }\end{array}$ & Std. Deviation \\
\hline 278 & 10 & 50 & 34.81 & .667 & 11.128 \\
\hline 278 & & & & & \\
\hline
\end{tabular}

Table 6 shows that the score of all the 278 respondents opinion varied between 10 which can be interpreted to mean strongly disagree and 50 which can be said to implied very strongly agree on all the 10 items. The mean of all the 10 items was recorded as 34.81 with a standard deviation of 11.128 . Standard error of the mean is 0.667 , small enough to suggest that the sample mean is true representative of the population mean. Since the mean 34.81 is within 3.50 tending towards 40 , it was concluded that respondents tended to agree on all the 10 items describing the performance appraisal on professional development variable.

Correlation between performance appraisal on professional development and teachers' performance

The study sought to establish the relationship between performance appraisal on professional development and teachers' performance. The researcher also tested the seventh null hypothesis, thus

\section{$\mathrm{H}_{0}$ : There is no significant relationship between performance appraisal on professional development and teachers' performance}

Correlation between the two variables was done using Pearson correlation index and results shown in table 7.

Table 7: Correlation between performance appraisal on professional development and teachers' performance

\begin{tabular}{|l|l|c|c|}
\hline \multicolumn{2}{|c|}{} & $\begin{array}{c}\text { Teacher appraisal on } \\
\text { Profession } \\
\text { development }\end{array}$ & $\begin{array}{c}\text { Teachers' } \\
\text { performance }\end{array}$ \\
\hline $\begin{array}{l}\text { Teacher appraisal on } \\
\text { Profession development }\end{array}$ & $\begin{array}{l}\text { Pearson } \\
\text { Correlation }\end{array}$ & 1 & $.801^{* *}$ \\
\cline { 2 - 4 } & Sig. (2-tailed) & 278 & .000 \\
\cline { 2 - 4 } & $\mathrm{N}$ & $.801^{* *}$ & 278 \\
\hline Teachers' performance & $\begin{array}{l}\text { Pearson } \\
\text { Correlation }\end{array}$ & .000 & 1 \\
\cline { 2 - 4 } & Sig. (2-tailed) & 278 & 278 \\
\cline { 2 - 4 } & $\mathrm{N}$ & & \\
\hline
\end{tabular}

Table 7 shows a correlation of $r=0.801$ with $p=0.000$. A correlation of $r=0.801$ implies that there is a very strong positive linear correlation between performance appraisal on professional development and teachers performance. This can also mean, as performance appraisal on professional development increases, teachers' performance increases too.

Testing of null hypothesis 7

This section test hypothesis four that states 'There is no significant relationship between performance appraisal on professional development and teachers performance. From table 4.33 a $\mathrm{P}$-value was found to be $\mathrm{p}=0.00$ which is less than 0.05 level of significant. This led to rejection of the null hypothesis and adoption of the alternative hypothesis that there is significant relationship between performance appraisal on professional development and teachers' performance. 
The study sought to determine how performance appraisal on professional development predicts teachers' performance. To help in this, a linear regression analysis was computed and based on the following model

$\mathrm{Y}=\mathrm{a}+\beta \mathrm{x}+\mathrm{e}$

Where

Y - Teachers' performance (Dependent variable)

A - Constant

$\beta$ - change in $Y$

$\mathrm{X}$ - Performance appraisal on professional development (Independent or Predictor Variable)

Regression analysis were presented in Table 8

Table 8: Regression model summary of performance appraisal on professional development on Teacher performance

\begin{tabular}{|c|c|c|c|}
\hline $\mathbf{R}$ & R Square & Adjusted R Square & Std. Error of the Estimate \\
\hline $.801^{\mathrm{a}}$ & .641 & .640 & 6.700 \\
\hline
\end{tabular}

Table 8 shows R Square of 0.641 with an adjusted $\mathrm{R}$ square of 0.640 . This implies that performance appraisal on professional development explains $64.1 \%$ variations in teachers' performance. In other words performance appraisal on professional development predicts teachers' performance by $64.1 \%$

The study further sought to determine whether the model represented in table 8 was fit and significant. This led to computation of ANOVA analysis as presented in Table 9.

Table 9: ANOVA table on performance appraisal on professional development and teachers' performance

\begin{tabular}{lccccc}
\hline & Sum of Squares & df & Mean Square & F & Sig. \\
\hline Regression & 22138.358 & 1 & 22138.358 & 493.200 & $.000^{\mathrm{b}}$ \\
Residual & 12388.850 & 276 & 44.887 & & \\
\hline Total & $\mathbf{3 4 5 2 7 . 2 0 9}$ & $\mathbf{2 7 7}$ & & & \\
\hline
\end{tabular}

Table 9 show statistics to ascertain whether the model which shows performance appraisal on professional development as a predictor of teachers' performance is fit. The results shows F $=493.200$ with P- Value $=0.00$. Since P-values was found to be less than 0.05 level of significant, it was concluded that the model was significant and that performance appraisal on professional development is a significant predictor of teachers' performance

The study sought to establish how a unit of performance appraisal on professional development led to increase in teachers' performance. The results were presented in table 10.

Table 10: Coefficients table of performance appraisal on professional development and teachers' performance

\begin{tabular}{|l|c|c|c|c|c|}
\hline \multirow{2}{*}{} & \multicolumn{2}{|c|}{$\begin{array}{c}\text { Unstandardized } \\
\text { Coefficients }\end{array}$} & $\begin{array}{c}\text { Standardized } \\
\text { Coefficients }\end{array}$ & \multirow{2}{*}{ Sig. } & \\
\cline { 2 - 6 } & $\mathbf{B}$ & Std. Error & Beta & & .000 \\
\hline (Constant) & 7.502 & 1.322 & & 5.675 & .000 \\
\hline $\begin{array}{l}\text { Teacher appraisal on } \\
\text { Profession development }\end{array}$ & .803 & .036 & .801 & 22.208 & \\
\hline
\end{tabular}

Table 10 shows that a unit of performance appraisal on professional development leads to an increase of 0.803 in teachers' performance. Based on P-Value of 0.00 as shown in table 10, this increase was found to be significant since $\mathrm{p}$ was less than 0.05 level of significant. If this statistics is substituted in the above mode

$\mathrm{Y}=\mathrm{a}+\beta \mathrm{x}_{4}+\mathrm{e}$

Then

$\mathrm{Y}=7.502+0.803(\mathrm{X})$ : where $\mathrm{X}=$ performance appraisal on professional development.

Interview findings illustrated that teachers have had positive attitudes towards professional development performance appraisals. This, according to the Principals, is due to the fact that most teachers hope that this exercise would lead to 
enrolment into INSET programs and eventually lead to professional growth. An outstanding theme emerging from the interviews could be summarised as:

Professional development performance appraisal do not get much resistance from most of our teachers. This arises due to the fact that training needs recommendations emanating from the exercise often lead to enrolment into INSET programmes. This leads to professional growth and to some extent, promotion.

\begin{abstract}
Discussions
The study found that professional development appraisal is a significant predictor of teachers' performance. Findings highlight the fact that approximately $64.1 \%$ change in performance of teachers is attributed to professional development appraisal. Indeed scholars have alluded to the fact that performance appraisals of employee development matches skills possessed and job demand hence recommending for specific improvements if need be. Several earlier studies on in-service teacher training (INSET) programs have come up with positive outcomes regarding performance of teachers after training. A study done in Pakistani by Junejo et al (2017) on the impact of in-service training on teacher performance revealed positive impact not only on performance but also perception of teacher regarding professional growth. Concurring findings were also found in Kwaku and Mensah (2016) during a study which explored the influence of teachers' continuous professional development (CPD) on classroom practices. They showed that teachers considered the professional development programmes to be relevant to their classroom management practices. However, the findings seem to contradict Norwani et al (2017) and Uysal (2012). The former, in a study which explored the relationship between the level of in-service training (IST) needs and teachers' teaching skills to students' achievement in Malaysia found a weak significant relationship between IST needs with teaching skills and no significant relationship between teaching skills and students' achievement. The latter, in an evaluation of the impact of a one-week INSET program in Turkey on language teacher' knowledge, found limitations in the program in terms of its planning and devaluation phases. It is thus emerging that the attitude of teachers towards professional development is positive although the programs may suffer inadequacies in providing the necessary skills required.
\end{abstract}

\title{
Conclusion
}

The study concludes professional development performance appraisal contributes highly to performance of secondary school teachers. It is also concluded that teachers have positive attitude towards professional development appraisal due to its potential in enhancing professional growth to teachers.

\section{References}

1. Abong'o, J.O. (2013). Effect of SMASSE in-service education and training on biology teachers' pedagogical skills and attitudes towards teaching biology in Rachuonyo south district, Homa Bay County. Unpublished thesis submitted to Egerton University

2. Adagiri, S.O. (2014). Comparative Study of Teachers' Continuing Professional Development (CPD) In Nigeria and England: A Study of Primary Schools in Abuja and Portsmouth. Unpublished study submitted to University of Portsmouth.

3. Ademola, S. (2017). Impact of performance appraisal on employee performance. International journal of economics and business management, 3 (1) 80-90.

4. Akhtar, I. (2016). Research design. Research in Social Science: Interdisciplinary Perspectives, Available at: https://www.researchgate.net/publication/308915548

5. Balta, N., Arslan, M \& Duru, H. (2015). The effect of In-Service training courses on teacher achievement: A meta-analysis study. Journal of Education and Training Studies, 3(5), 254 - 264

6. Boko, J.M., Danku, S.W., Dordor, F. \& Soglo,N. Y.(2015) performance appraisal in the Ghana Education servicer. International journal of managerial studies and research, 3 (6) 117-133.

7. Boyan, S. (2013).The origin, concept and value of performance appraisal. International journal economics, commerce and management, 1 (2) 1-17.

8. Braun, V. and Clarke, V. (2019). Reflecting on reflexive thematic analysis, Qualitative Research in Sport, Exercise and Health, 11:4, 589-597, DOI: 10.1080/2159676X.2019.1628806

9. County Education Office (CEO, 2019). Migori. Performance of Secondary Education Teachers: Continuous performance appraisal. Government Press, Nairobi.

10. County Education Office (CEO, 2021). Migori. Performance of Secondary Education Teachers: Continuous performance appraisal. Government Press, Nairobi.

11. Creswell, J. W., \& Plano C. V. L. (2018). Designing and Conducting Mixed Methods Research (3rd ed.). Sage Publications. 
12. Darling-Hammond, L., Hyler, M. E., and Gardner, M. (2017). Effective Teacher Professional Development. Palo Alto, CA: Learning Policy Institute.

13. Dawadi, S., Shrestha, S., \& Giri, R. A. (2021). Mixed-Methods Research: A discussion on its types, challenges, and criticisms. Journal of Practical Studies in Education, 2(2), 25-36 DOI: https://doi.org/10.46809/jpse.v2i2.20.

14. Dessler, G. (2014). Human Resource Management. (12th ed.). Upper saddle River, N. J: Person Education, line

15. Gichuki, G.M. (2015) Teachers perceptions of the performance appraisal system effectiveness. Unpublished dissertation, Kenyatta University

16. Junejo, M.I., Sarwar, S. and Ahmed, R.R. (2017). Impact of In-Service Training on performance of teachers: A Case of STEVTA Karachi Region. International Journal of Experiential Learning \& Case Studies, 2 (2), 50-60.

17. Kareithi, M.W. (2018). Effect of performance appraisal system on performance of secondary schools' teachers in Kirinyaga West Sub-County, Kenya. Unpublished dissertation submitted to KCA University

18. Kirai, M. \& Kisang, F. (2016). Effects of performance appraisal on employee motivation. The strategic journal of business \& change management, 3(4)521-542.

19. Kwaku, D and Mensah, D (2016). Teacher professional development: keys to basic school teachers' curriculum practice success in Ghana. International Journal of Interdisciplinary Research Method, 3(2), 33-41.

20. Matula, P. D., Kyalo, D. N., Mulwa, A. S., \& Gichuhi, L. W. (2018). Academic Research Proposal Writing: Principles, Concepts and Structures. Nairobi: ACTS Press.

21. Namamba, A. and Rao, C. (2017). Preparation and Professional Development of Teacher Educators in Tanzania: Current Practices and Prospects. Journal of Education and Practice 8(8), 136 - 145

22. Nanjundeswaraswamy, T.S. and Divakar, S. (2021). Determination of sample size and sampling methods in applied research. Proceedings on Engineering Sciences, 03, (1), 25-32.

23. Norwani, N.M., Daud, W.M.N., Mansor, M. and Yusof, R. (2017). The relationship between In- Service Training and Teaching Skills with Student Achievement. International Journal of Academic Research in Business and Social Sciences, 7 (12), $61-76$.

24. OECD. (2009). Creating Effective Teaching and Learning Environments: First Results from TALIS. Paris: Organization for Economic Co-Operation and Development. http://www.oecd.org/document/54/0,3343,en_2649_39263231_42980662_1_1_1_1,00.ht ml.

25. Opfer, V. D. \& Pedder, D. (2011). The Lost Promise of Teacher Professional Development in England', European Journal of Teacher Education, 34(1), 3-24.

26. Raholdina-Razafimbelo, J. Razafimbelo, C. Ramanitra, N., M., Andrianavalonirina, A. \& Ratompomalala, H. (2013). Professional Development for Primary School Teachers in Madagascar: Around Teachers' Network. Journal of International Cooperation in Education, $15 \quad$ (3), 59 76.

27. Shorten A., \& Smith J. (2017). Mixed methods research: Expanding the evidence base. Evid Based Nurs, 20, 74-5. http://dx.doi.org/10.1136/eb-2017-102699

28. Taherdoost, H. 2016. How to Design and Create an Effective Survey/Questionnaire; A Step by Step Guide. International Journal of Advance Research in Management, 5(4), 37-41.

29. Uysal, H.H. (2012). Evaluation of an In-service Training Program for Primary-school Language Teachers in Turkey. Australian Journal of Teacher Education, 37 (7), 14 - 30. 